\title{
Factors driving Thailand rice farmer decision-making in the choice of marketing channel
}

by Thamthanakoon, N., Huang, I.Y., Eastham, J., Ward, S. and Manning, L.

Copyright, publisher and additional information: .This is the author's accepted manuscript. The original version is also available via Emerald.

Please refer to any applicable terms of use of the publisher

DOI link to the version of record on the publisher's site

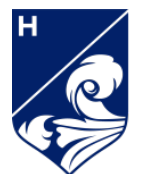

Harper Adams University 
Factors driving Thailand rice farmer decision-making in choice of marketing channel

Nithicha Thamthanakoon ${ }^{\mathrm{a}}$, Iona Y Huang ${ }^{\mathrm{b} *}$, Jane Eastham ${ }^{\mathrm{c}}$, Shane Ward ${ }^{\mathrm{d}}$, Louise Manning $^{\mathrm{e}}$

a Department of Agricultural and Resource Economics, Faculty of Economics, Kasetsart University, Bangkok, Thailand

b Department of Land, Farm and Agribusiness Management, Harper Adams University, Newport, Shropshire, UK

c Department of Food Science and Agri-Food Supply Chain Management, Harper Adams University, Newport, Shropshire, UK

d School of Biosystems \& Food Engineering, University College Dublin, Ireland e School of Agriculture, Food and Environment, Royal Agricultural University, Cirencester, Gloucestershire, UK

*Corresponding author. Tel: +44 1952815156

E-mail address: ihuang@harper-adams.ac.uk

Declaration of Interests: none

Research funding: No external funding received.

2 Accepted for publication by British Food Journal on 16 June 2021.

3 DOI: 10.1108/BFJ-11-2020-1040

4 


\section{Abstract}
5 Purpose: Since the end of the latest Rice Pledging Scheme, Thai rice farmers have had more
6 freedom in selecting marketing channels. Understanding the determinants of farmers' decision-
7 making associated with these channels is of particular interest to multiple stakeholders in the rice
8 value chain. This study aims to examine how economic, relational, and psychological factors
9 concurrently underpin Thai rice farmers' decision making and influence their marketing channel

10 choice.

11 Design/methodology/approach: Drawing on the Theory of Reasoned Action and utility

12 maximization of farmers' decision making, this study used structural equation modelling to

13 examine data collected from a nationwide sample of Thai rice farmers $(n=637)$, focusing on their

14 past and intentional use of the three major marketing channels for paddy rice.

15 Findings: The determinants identified include four direct independent variables: attitude,

16 subjective norm (social referents), transaction conditions and economic goals, and two indirect

17 independent variables: past behavior and trust. Multi-group analysis suggests that rice co-

18 operative users were more empowered to consider economic goals and attitude towards the

19 channel, whilst rice miller and local collector users were more likely to be influenced by their

20 social referents and the transaction conditions offered by the channel.

21 Originality: Our study makes a unique and substantive contribution to the knowledge of

22 farmers' decision-making about marketing channel choice in Thailand and theoretically the

23 indirect role of past behavior in predicting prospective intention.

24 Practical implications: The findings highlight the need for policy to address trust and

25 transparency issues with intermediaries and to empower farmers through improvement of market 26 access. 


\section{Introduction}

Market participation of farmers has been seen as a fundamental part of rural development in developing countries. Marketing channels play a critical role in linking farmers to markets (Fischer and Qaim, 2014). There are different types of market channels for primary producers ranging from informal markets through several business model iterations to formal trading channels such as contract farming or trading through a range of intermediaries (Shepherd, 2007).

There is a growing academic interest in farmers' marketing channel use. Within this literature, most tend to focus on high-value products (Tsourgiannis et al., 2008; Milford, 2014), and/or modern channels such as collective sales (Fischer and Qaim, 2014; Zhang et al., 2017), export (Stanton and Burkink, 2008; Arinloye et al., 2015) or contract farming arrangements (Schipmann and Qaim, 2011; Barrett et al, 2012). As suggested by Poole (2017), domestic markets for staple grain crops, characteristically produced by emerging and semi-subsistence farmers in developing countries, contribute more to broad-based rural development due to the scale of such farmers.

Some recent studies have considered marketing channel use and their efficiency associated with paddy and/or milled rice specifically in Tanzania (Mgale and Yunxuan, 2020); India (Kakati and Chakraborty, 2017; Kumar et al., 2019); Vietnam (Pham et al., 2019) and Indonesia (Yonida et al., 2020). Whilst direct selling to consumers or retailers has increasingly been used for milled rice (Kakati and Chakraborty, 2017; Kumar et al., 2019; Yonida et al., 2020), the main marketing channels highlighted for paddy rice were traditional channels such as local agents/collectors, rice millers and wholesale traders (Kakati and Chakraborty, 2017; Kumar et al., 2019; Pham et al., 2019; Mgale and Yunxuan, 2020), and modern farmer organizations (Pham et al., 2019; Mgale and Yunxuan, 2020).

Thailand is one of the main rice producers in the world (FAO, 2018) with $46 \%$ of total agricultural land dedicated for rice production (OAE, 2019). Nationally, 79.9\% of rice farmers (3.5 million) are small-scale farmers with less than 3.2 hectares of land per household (OAE, 2019). The vast majority of small-scale farmers are located in the Northeast and North regions 
(83.23\% and $77.63 \%$ respectively) (OAE, 2019). This sector has experienced successive policy interventions ranging from low-interest loans to rice farmers to fixed higher-than-market price for paddy rice (Poapongsakorn and Pantakua, 2014; Ricks and Laiprakobsup, 2021). Four main marketing channels for paddy rice have been used by rice farmers in Thailand (Srisompun, 2014). They are: agricultural cooperatives, local collectors (or middlemen), rice millers and central paddy market. The interventions, most notably, a series of Rice Pledging Schemes (RPS), were often associated with the promotion of particular market channels (Liese et al., 2014). Therefore, the share of any specific rice marketing channel would vary under different policy intervention schemes (Poapongsakorn, 2010). For example, central paddy markets, established in 1980, had a market share of nearly $24 \%$ by 1997 (Isvilanonda, 2010) due to the fact that the initial RPS was implemented by the Bank for Agriculture and Agricultural Cooperatives which operated in central paddy markets. However, the RPS introduced in 2011 favoured rice millers more (Ricks and Laiprakobsup, 2021). By 2013, the share of central paddy markets dropped by near half to $12.59 \%$ (Srisompun, 2014). The RPS ended in 2014 (Ricks and Laiprakobsup, 2021). It is possible that the channel use may have changed again since then. Thai rice farmers have had more freedom in selecting marketing channels, so understanding the determinants of farmers' decision-making associated with these channels is of particular interest to multiple stakeholders in the rice value chain.

In terms of the rationale behind the farmers choice of marketing channel, some studies have taken a socio-economic perspective, focusing on characteristics such as level of education, farm size, location, and social network (Abebe et al., 2016; Pham et al., 2019; Mgale and Yan, 2020), transaction cost analysis (Escobal and Cavero, 2012; Mgale and Yan, 2020), utility maximization (Blandon et al., 2010) or asset specificity (Pham et al., 2019). Other studies incorporate relationship dynamics between channel members such as power and trust (Schipmann and Qaim, 2011; Abebe et al., 2016; Mgale and Yunxuan, 2020). 
Since Gasson's (1973) seminal study, farmers' goals and objectives have featured highly in much empirical research on farmers' decision-making (Beedell and Rehman, 2000; Borges, 2015). In the context of economic decision-making, a framework relevant to farmers' goals is expected utility maximization (Nuthall and Old, 2018). If the farmer acts purely as an economic agent they would select a marketing channel by evaluating the expected utility or net benefits of the channel (Blandon et al., 2010; Arinloye et al., 2015). Profit is one aspect of the expected utility, but other aspects include incentives received from buyers (Arinloye et al., 2015), and payment mechanisms and grading (Blandon et al., 2010).

The Theory of Reasoned Action (TRA) (Fishbein and Ajzen, 1975) and its later variant the Theory of Planned Behavior (TPB) (Ajzen, 1991; 2011) are used widely to study farmers' decision-making (Burton, 2004; Hansson et al., 2012; Meijer et al., 2015). However, its application to farmers' marketing channel choice has generally been limited (Dunay et al., 2018). Dunay et al. (2018) found that attitudes and subjective norms, key exogenous factors in the TRA, along with goals and objectives, strongly influenced farmers' decision-making. Considering that farmers do not always make purely economic or economically optimal decisions (Howley, 2015; Howley et al., 2015), we see the need to apply social-psychological perspectives to studies associated to farmers' decision making. Our lens of enquiry is marketing channel choice by rice farmers in Thailand. This study aims to examine how economic, relational, and psychological factors concurrently underpin farmers' decision making and influence marketing channel choice by Thai rice farmers. Our study makes a unique and substantive contribution to existing knowledge of farmers' decision-making about marketing channel choice in Thailand.

\section{Theoretical Framing of the Study}

We propose an integrated framework (Fig. 1) illustrating the key decision factors influencing farmers' marketing channel use behavior. As a central premise, TRA identifies that conscious cognition is a causal agent in decision making and choice (Fishbein and Ajzen, 1975; Ajzen, 
1991; 2011). According to Fishbein and Ajzen (1975), an individual's intention to perform a

105 behavior is an immediate antecedent of that prospective behavior and the intention is influenced by that individual's attitude towards the behavior and subjective norms (social influences from friends, family, experts, policy makers etc.). Our framework extends the TRA model by drawing upon economic goals and transaction conditions to develop a more holistic overview of farmers' decision-making regarding marketing channel choice.

\section{Take in Figure 1 here}

\subsection{Past behavior and intention}

112 It is important to note that there are three aspects of behavior: retrospective behavior, intention and prospective behavior. According to Fishbein and Ajzen (2010), empirically, many studies

114 based on self-report surveys have assessed intentions and past (retrospective) behavior at the

115 same time. Based on the conclusions of several meta-analyses of the relationship between

116 intention, prospective behavior (Armitage and Conner, 2001) and/or retrospective behavior

117 (Albarracin et al., 2001), Fishbein and Ajzen (2010) concluded that "intentions are found to

118 predict behavior quite well" (p.51) whilst acknowledging that the findings from the meta

119 analyses were inconsistent in that "intentions sometimes predict past behavior better than future

120 behavior but at other times predict future behavior better than past behavior" (p. 50). We argue

121 that current intention cannot be used as a predictor of past behavior because prediction is about

122 the future not the past and temporal precedence is one of the criteria for prediction (Kenny, 1979;

123 Hair et al., 2013). Ajzen (1991; 2011) explicitly points out that past behavior does not constitute

124 a causal antecedent of intention due to its lack of regularity. We, therefore, propose that past

125 behavior exerts influence on intention indirectly, through the outcomes of the appraisal of the

126 channel used, typically including attitude towards and trust in the channel. Past behavior itself is

127 influenced by subjective norm, economic goal and transaction condition offered.

\section{$128 \quad 2.2$ Attitude and subjective norm}


Attitude is a latent disposition defined as the decision maker's favorable or unfavorable

130 evaluation of the performance of a particular behavior or as a response to a given behavior

131 (Fishbein and Ajzen, 1975; 2010). Commitment to a given marketing channel is empirically

132 linked to two evaluative attitudinal constructs: satisfaction, informed by past experience (Selnes,

133 1998; Schirmer et al., 2018) and trust. Trust entails a channel member's belief in an exchange

134 partners' integrity or honesty (Morgan and Hunt, 1994). In line with the TRA framework which

135 sees attitude as the antecedent of behavior, we delineate causal paths from past behavior to trust

136 (H1a), trust to attitude (H1b), past behavior to attitude (H1c), and from attitude to channel use

137 intention (H1d) as shown in Figure 1.

138 Subjective norm is narrowly defined in the TRA framework as perceived social pressure to

139 perform (or not to perform) a particular behavior (Fishbein and Ajzen, 2010) that can inform

140 channel use intention. Social pressure to perform a given behavior can arise in the context of this

141 study from extension officers, neighbors and peer groups, and family members (Meijer et al.,

142 2015; van Dijk et al., 2016). We therefore propose causal paths from subjective norm to past

143 behavior $(\mathrm{H} 2 \mathrm{a})$ and from subjective norm to intention $(\mathrm{H} 2 \mathrm{~b})$ as shown in Figure 1.

\section{$144 \quad 2.2$ Economic goal and transaction condition}

145 We delineate two categories of utility maximization intrinsic to market exchange: economic

146 goals held by farmers and consideration of transaction conditions offered by the channel. These

147 can be achieving higher price, lower costs of selling or better cash flow, depending on individual

148 farmers' circumstances. Price per se is rarely the sole determining factor (Tsourgiannis et al.,

149 2012), particularly when the heterogeneity in socioeconomic characteristics of farmers and farm

150 is taken into consideration (Hansson et al., 2012). Cost-focused farmers are more motivated by

151 reducing costs than achieving a higher price (Tsourgiannis et al., 2012) or having a healthy cash

152 flow (Blandon et al., 2010). Whilst economic goals are about what farmers want to achieve

153 through a transaction, the other side of the coin is the transaction conditions offered by the

154 channel (Shepherd, 2007). Indeed, farmers are concerned not only with the price offered but also 
155

156

157

158

159

160

161

162

163

164

165

166

167

168

169

170

171

172

173

174

175

176

177

178

179

channel accessibility, mode and speed of payment, grading and standard, purchase volumes of buying and other costs of selling such as transportation (Blandon et al., 2010; Tsourgiannis et al., 2008; 2012; Arinloye et al., 2015). In summary, we propose causal paths from economic goal to past behavior (H3a), from economic goal to intention ( $\mathrm{H} 3 \mathrm{~b})$, from transaction condition to past behavior (H4a) and from transaction condition to intention (H4b) as shown in Figure 1.

\section{Materials and methods}

\subsection{Study area, sampling and data collection}

This study focuses on understanding the factors that influence rice farmers' choice of marketing channel. The study area covered three of the four geographical regions in Thailand: North, Northeast and Central regions with a collective share of $98.5 \%$ of the total rice production in Thailand (OAE, 2019). A two-phase sequential approach was adopted for data collection. Phase one involved preliminary in-depth interviews conducted in 2015 with 33 rice farmers from three provinces as shown in Figure 2a. The interviews aimed to explore marketing channel choice and validate/inform the development of the measures of the key concepts as depicted in Figure 1.

The findings of the interviews were used to inform the phase-two survey in relation to questionnaire design, sampling and the actual data collection process. Phase two cross-sectional survey questionnaires were collected in person in 2016 from nine provinces as shown in Figure $2 \mathrm{~b}$ and produced the main data for this study.

\section{Take in Figure 2 here}

To ensure a representative sample, the selection of the provinces and villages took into consideration three main factors: the number of crops, farm size and rice varieties. For phase-one interviews, a theoretical sampling was used to select one representative province for each region. Two villages in each province were selected at the recommendation of the sub-district administrative organization (SAO) in each region. Individual rice farmers were identified by the Agricultural Extension Officers (AEO) based on the criteria provided by the researchers. For the 
second stage survey, a three-step sampling procedure was adopted. Three representative

181 provinces in each region were firstly selected based on the agricultural census data for each

182 province. This is followed by selecting villages from the nine chosen provinces with the

183 assistance of the administration officers of the SAO and AEOs in each province, leading to the

184 identification of a total of 21 villages (four in the North, seven in the Northeast and ten in the

185 Central region). Finally, the respective SAO or AEO helped send requests for assistance to the

186 head of villages, or government officers attached to the village, who called an assembly in the

187 village and promoted the survey to the individual rice farmers.

Phase-one interviews were conducted face-to-face and fully recorded by the first author.

Phase two questionnaires were distributed and collected in person by the first author and three assistants under the supervision of the first author. Prior to the data collection, the assistants were all trained by the first author. A total of 661 valid questionnaires were collected, 24 of which reported using channels which were excluded for detailed analysis due to small sizes of subgroups. Therefore, the main data analysis was based on responses from 637 rice farmers, selling rice to any of the three main marketing channels: millers, local collectors and cooperatives. The specific number of respondents from each province can be found in Figure $2 b$.

\subsection{Questionnaire design and measures of analytical variables}

The questionnaire was designed to collect information for analytical variables as specified in the proposed model (Figure 1) and also relevant socio-demographic information. Particular attention was paid to specific and precise wording. Findings from the preliminary in-depth interviews were used to contextualize the measures for Thai rice farmers where appropriate. Measures for

201 the variables in the proposed model were also developed through synthesis of the scales established from previous studies (Selnes, 1998; Fishbein and Ajzen, 2010; Hernández-

203 Espallardo et al., 2012).

Two channel use behavioral variables were proposed in the conceptual framework: past 
rice they sold to any of the three channels between February 2014 (end of last RPS) and June 2016 (when survey conducted). The scale ranged from "never", then "less than 10\%" to "always - over 90\%" against each channel. Intention, defined as the likelihood of a farmer selling the next rice crop to use any particular marketing channel, was measured using the statement "Next crop, I intend to sell to this marketing channel" scaling from most unlikely (1) to most likely (7). The influencing variables considered were attitude, trust, subjective norms and economic goal and transaction conditions. All variables were measured with 7-point scale. For the variable economic goal, respondents were asked to indicate the level of importance from 'not important at all' (1) to 'extremely important' (7). All other variables were measured using Likert scale (from $1=$ strongly disagree to $7=$ strongly agree) against each relevant statement.

Attitude towards a particular channel used was seen as a latent predisposition as shown in either a favorable or unfavorable manner (Fishbein and Ajzen, 2010). Two evaluative statements (adapted from Hernández-Espallardo et al., 2012) were used to measure attitude: "This channel is a good choice for me" and, "Overall, I am happy with this channel". Trust was measured using two items in relation to honesty/integrity and reliability (Morgan and Hunt, 1994). The two items were: "I choose this channel because I don't have to worry about being cheated on: 1) the weighing scale and 2) rice quality grading assessment".

Subjective norms were measured against five normative referents: friends and/or neighbors, family members, government officers, mass media and harvest machine drivers (all validated through phase-one interviews). The statement used were adapted from Fishbein and Ajzen (2010): "Most of my friends and neighbors sell their rice to this channel"; and "My family member/Government officer/Rice harvest machine driver recommend that I should sell to this channel".

The construct, economic goal, was measured with three items identified from preliminary interviews and extant literature (Blandon et al., 2010; Tsourgiannis et al., 2012). The three goals were: selling at a higher price, minimizing cost, and enhancing cash flow. Transaction conditions 
offered by the channel were measured with items adapted from Blandon et al. (2010) and

233 Tsourgiannis et al. (2012) and contextualized after the preliminary interviews. Transaction

234 condition was conceptualized to include mode of payment, buying capacity, costs of selling and

235 accessibility offered by channels. The items for transaction conditions provided by a specific

236 channel included: cash payment, confidence in being paid, buying any quantity, easiness to

237 access, price offer and cost of transportation.

All measures of the variables in the proposed model were tabulated in the questionnaire against each specified marketing channel previously used or where there was an intention to use.

240 Common method bias was checked by using Harman's single factor test. Constraining the

241 number of factors extracted to one, the total variance explained by all indicators of the

242 independent variables was $27.31 \%$, which showed that common method bias was not an issue for

243 the observed items of the determinant factors.

\section{$244 \quad 3.3$ Analytical procedure}

245 Socio-demographic characteristics of the respondents were first summarized. Descriptives of the analytical variables were explored. ANOVA test was used to compare the differences of sociodemographic attributes across the sub-groups of different channel users.

The proposed model was tested based on the main survey data using covariance-based structural equation modelling (SEM) with AMOS 26. SEM tests a series of regression equations

250 simultaneously, encompassing the modelling of correlated independents, measurement error, multiple latent independent and dependent variables with single or multiple observed indicators, path analysis and analysis of covariance (Blunch, 2013; Hair et al., 2017). Maximum likelihood estimation was used to infer the value of the unobserved, or latent variables. This method makes use of full information or all data points available (Arbuckle, 2017). A two-step strategy

255 (Blunch, 2015) for SEM was adopted, followed by multi-group analysis. 
The first step was a confirmatory factor analysis (CFA) or measurement modelling of the

257 observed and latent variables. Model fit was assessed using standard model fit indices. To assess 258 the model fit, the criteria provided by Hair et al. (2013) were adopted. The indices suggested by Hair et al. (2013) vary slightly according to sample size (N) and number of measures or indicators $(\mathrm{m})$. They suggested that if $\mathrm{N}>250$ and $12<\mathrm{m}<30$, the significant $\mathrm{p}$-values for likelihood ratio chi-square expected should be less than $.05(\mathrm{p}<.05)$, comparative fit index (CFI) 262 should be greater than .92, room mean square residual (RMR) should be less than.08, and the root mean square error of approximation (RMSEA) be less than .07. Minor modifications were made according to the modification indices for the covariances produced by AMOS. As a result, two indicators ('government officer' and 'rice harvest machine driver') for the latent variable 'subjective norm', and two for the latent variable 'transaction condition' ('Price offer' and 'cost 267 of transportation') were deleted.

Secondly, structural equation modelling was run based on the modified measurement model and structure of the proposed relationship between the latent variables. For the two singleindicator channel choice variables (i.e. past behavior and intention), Hayduk and Littvay's (2012) approach was used to fix the measurement error variances of the two items. Therefore, 0.1 was assigned to the error of past behavior and 0.3 to the error of intention, assuming less 273 error for actioned practice than predictive actions. One modification was done to improve the structural model fit. Details are provided in the results section. Thresholds for model fit assessments (Hair et al., 2013) can be found in Table 3.

Finally, multi-group analysis (MGA) for different user groups of rice marketing channels was conducted based on the modified structural model. The MGA compared the differences of 278 the model structure and individual path coefficients (standardized regression weights) across the 279 subgroups.

\section{Results}


The socio-economic characteristics of the sample population of rice farmers across the three

283 regions in Thailand are presented in Table 1. Of the 637 rice farmers who sold rice to any of the three main marketing channels (i.e. millers, local collectors or co-ops), 27 percent were (170 farmers) were from the North region, 46 percent (293 farmers) were from the Northeast and 27 percent (174 farmers) were from the Central region. There were 384 female farmers $(60 \%$ of the total). The average age of the respondents were 52 years. On average, the farmers received about 4 years of formal education. The average farm size was 8.7 Rais (1.4 ha) in the North region, 9.7 Rais (1.5 ha) in the Northeast and 26.2 Rais (4.2 ha) in the Central region. When compared with the agricultural census conducted by the National Statistical Office, Thailand (OAE, 2019), the sample is largely representative of rice farmers in Thailand in terms of education and farm size. Females and older farmers were slightly over represented in this sample.

\section{Take in Table 1 here}

In terms of the marketing channel used for selling rice, 369 farmers $(57.9 \%$ of the 637 respondents) sold rice to a miller, 120 farmers (18.8\%) to a cooperative and 201 farmers $(31.6 \%)$ to a local collector. The majority of the farmers only sold rice to one channel (91.9\%) and 49 respondents used two marketing channels and two used all three channels. For respondents who selected more than one channel, their responses for each channel were treated separately. This means the final sample for the SEM analysis was a pooled sample with a total of 690 channelspecific responses.

$$
\text { Statistically significant differences in channel used were found when region, gender, }
$$
education and farm size were considered (Table 1). Chi-Square test of independence indicated that millers and local collectors were used more by farmers in the Northeast region whilst cooperatives were used more by those in the North region $\left(\mathrm{X}^{2}=56.065, \mathrm{p}<.001\right)$. Female farmers were more likely to use local collectors $\left(X^{2}=6.65, p=.036\right)$. When compared by education, those who had completed more than seven years of education were more likely to use 
cooperatives $\left(X^{2}=29.06, p<.001\right)$. Those who farmed more than 12 Rais (or 1.92 ha) of rice were

308 more likely to have used millers $\left(X^{2}=20.16, p<.001\right)$.

309 4.2 Modelling results of determinants of paddy rice marketing channel use

310 SEM analysis involved confirmatory factor analysis (CFA) of the measurement model, structural 311 modelling and multi-group comparisons. The good model fit thresholds and indices were 312 explained in section 3.3 and also presented in Table 3.

The initial CFA was based on the original 19 observed indicators of the seven latent

314 variables of the proposed model as shown in Figure 1. The results showed poor model fit $315\left(\mathrm{X}^{2}=630.59\right.$ with $\mathrm{df}=126$ and probability level $=.00 ; \mathrm{X}^{2} / \mathrm{df}=5.01 ; \mathrm{CFI}=.859 ; \mathrm{RMSEA}=.078$, 316 PCLOSE $=.000, \mathrm{~N}=690$ ). Based on the modification indices and regression weights, four items 317 with large modification indices were removed as explained in section 3.3. The modified CFA 318 model (Model 2) with the remaining 15 indicators was improved to a good fit $\left(\mathrm{X}^{2}=171.597\right.$ with $319 \mathrm{df}=71$ and probability level=.00; $\mathrm{X}^{2} / \mathrm{df}=2.417 ; \mathrm{GFI}=.967 ; \mathrm{CFI}=.964 ; \mathrm{RMSEA}=.045$ and 320 PCLOSE=.804, $\mathrm{N}=690)$.

Convergent and discriminant validity of the five latent variables based on the modified measurement model were then examined. The validity test results for all five latent variables were shown in the last section of Table 2. The average variance extracted (AVE) is used to test convergent validity. The recommended level is greater than 0.50. The AVE of attitude, trust and subjective norm were above 0.5. Transaction condition and economic goals were below 0.5.

326 However, considering the exploratory nature of this study and other conditions being met, we 327 decided to retain the constructs. Discriminant validity is confirmed because all square root of 328 AVE (diagonals in the table) is greater than inter-construct correlations. Maximum shared 329 variances (MSVs) were all less than AVEs. Construct/composite reliability (CR) measures the 330 inherent consistency of the indicators of a construct. A CR coefficient of greater than 0.6 is 331 considered acceptable (Hair et al., 2017). CRs of the five latent variables in the present study ranged from 0.601 to 0.842 . 
Table 2 presents the descriptive statistics for the two behavioral variables (intention and past behavior) and the five AMOS-imputed factor scores of the five determinant latent variables. It can also be seen in Table 2 that statistically significant differences in the means value of intention $(\mathrm{p}<.05)$, past behavior $(\mathrm{p}<.01)$, attitude $(\mathrm{p}<.10)$, trust $(\mathrm{p}<.01)$ and transaction conditions $(\mathrm{p}<.0)$ were found across different channel user groups. Local collector users reported the highest frequency of past use of this channel and highest level of intention to sell to 340 this channel whilst co-op users reported the lowest of both. Local collector users also had the 341 highest rating on attitude towards this channel, trust in this channel, and transaction condition offered by the channel. Miller was the least trusted channel and the transaction condition of the co-op was rated the lowest by their users. Subjective norm and economic goals showed no statistically significant differences across the three channels $(\mathrm{p}=.26$ and .71 respectively).

The CFA model fitting retained 15 observed items which were subjected to structural equation modelling with AMOS. The proposed model (Model 1) was first tested, and the model 347 fit indices and results are presented in column 3 of Table 3. Model 1 had poor model fit indices 348 with none meeting the standard threshold (see column 2 of Table 3). Examination of the 349 modification indices suggested that a covariance should be added between the error terms of past 350 behavior (e14) and intention (e15) (M.I.=129.468). Adding the covariance between the two error 351 terms led to much improved model fit indices as shown in Model 2 (column 4 of Table 3) with 352 all model fit indices better than the thresholds shown in column 2. A Chi Square difference test 353 showed statistically significant difference between model 1 and model 2 ( $p$ <.0001). The 354 modified model with path coefficients is presented in Figure 3. 
All causal paths in model 2 apart from the one from $\mathrm{H} 3 \mathrm{~b}$ (economic goal to intention) were

statistically significant and the statistical estimates can be found in Table 4 . The factors identified in the model account for $48.2 \%$ of the variance of farmers' intentional channel use $\left(R^{2}=.482\right)$. Subjective norm, economic goal and transaction condition have statistically significant and strong influence on past behavior $\left(R^{2}=.75\right)$ with transaction condition being the strongest influencing factor for past behavior (std. $\beta=.476, \mathrm{p}<.001$ ).

\section{Take in Table 4 here}

Given the statistically significant differences found in intention, past behavior, attitude, trust and transaction condition amongst the three marketing channels, it is important to conduct a multiple group analyses (MGA) on the structural weights of model 2 based on channel used.

Table 4 presents the MGA results. This includes the structural weights coefficients (standardized regression), the significance probability ( $\mathrm{p}$ value) for each structural path and the results of comparison of each individual path. The MGA showed statistically significant differences in model structural weights amongst the three channels $\left(X^{2}=92.338 ; \mathrm{df}=36 ; \mathrm{p}<.0001\right)$. For rice miller users, all but one hypothesized causal path were supported. The exception was H3b (economic goal to intention). For local collector users, three hypothesized causal paths not supported were: H1d (attitude to intention), H3a (economic goal to past behavior), and $\mathrm{H} 3 \mathrm{~b}$ (economic goal to intention). For cooperative users, four causal paths were not supported. They were: $\mathrm{H} 1 \mathrm{~b}$ (trust to attitude), $\mathrm{H} 3 \mathrm{a}$ (economic goal to past behavior), $\mathrm{H} 2 \mathrm{~b}$ (subjective norm to intention) and $\mathrm{H} 4 \mathrm{~b}$ (transaction condition to intention). Interestingly, cooperative users' intention to continue using this channel seemed to be mainly motivated by economic goals, which was in direct contrast with those selling to millers and local collectors whose intention was mainly influenced by subjective norm and transaction condition offered by the channel. 


\section{Discussion}

381 Thai rice farmers have mainly relied on rice millers, local collectors and cooperatives to take 382 paddy rice to market. Over 90 percent of the farmers used one channel only. This is extremely 383 high compared to the proportion (47.9 percent) found in Tanzania rice famers (Mgale and 384 Yunxuan, 2020). Of the three channels, miller and local collector were the two most commonly 385 used channels in all three regions. Bigger farmers were more likely to use millers and smaller 386 farms more likely to use local collectors. Cooperatives were used more by those with higher 387 level of education. Those findings are largely consistent with observations in other countries 388 (Pham et al., 2019; Mgale and Yunxuan, 2020). Aside from the socio-demographic 389 characteristics of channel users, the hypothesized causal paths to the farmers' past channel use 390 (i.e. past behavior) and intentional use were largely confirmed despite some nuances found 391 amongst the users of the three channels.

The role of past behavior was an unresolved issue for TRA/TPB (Fishbein and Ajzen, 2010). Our data supported the hypothesized causal paths that past behavior was influenced by subjective norm and transaction condition across all three channel user groups. Past behavior was also influenced by economic goals for those selling to millers. As for the relative importance 396 of the influencing factors, transaction condition and subjective contributed more to the past channel choice than economic goal. The proposed influence of past behavior on attitude either directly or indirectly via trust was also supported by the data. This enriches existing understanding of the role of past behavior in TRA/TPB framework and is worthy of application

400 in other sectors and behavioral contexts.

Attitude was shown to have statistically significant, albeit weak, influence on intention of using millers and cooperatives, but not local collectors. Attitude was formed directly through past experience of the channel use (past behavior) and indirectly via trust through the construct of operational honesty in grading and weighing particularly for miller and local collector users. 
channel affects their choice of millers and large-scale traders. It also partly concurs with Schipmann and Qaim, (2011) who suggested that lack of trust in grading processes was one of the reasons for farmers to withdraw from a given marketing channel. However, the trust-attitude path was not supported by those who sold to cooperatives.

Subjective norm in the form of family/friends and neighbors was found to have consistently influenced past behavior in all situations and influenced intention to use local collectors and millers, but not cooperatives. This partly corroborates the findings of van Dijk et al. (2016) that farmers tend to be influenced by their immediate social referents. Pham et al. (2019) and Mgale and Yan (2020) both found that access to marketing information affects rice farmers' channel choice in Vietnam and Tanzania. Friends and neighbors could be important sources of market information for Thai rice farmers.

Farmers' expected utility maximization in the forms of economic goal and transaction condition is of varied influence in this study. Economic goal to intention path was not supported by miller and local collector users. This partially supports the findings of some previous studies (Howley et al., 2015; Abebe et al., 2016) that famers' decision may not always follow a purely economic rationale and that in developing countries smallholder farmers tend to trade via middlemen even if the profit margin is low especially if there is a personal relationship with the collector (Pham et al., 2019). The level of activity required from the farmer in engaging with these different marketing channels has also been shown to be of influence e.g. if the rice is collected from the farm gate or if the farmer has to take the rice to the mill (Kakati and Chakraborty, 2017), mediated in part by whether the farmers have access to personal transport (Pham et al., 2019). Mgale and Yunxian (2020) also echo this finding that most farmers in their study still sell through local collectors. They cite distance to market and also inability to act outside the farm gate. Also critical is the direct contrast with cooperative users who were perhaps more empowered through collective action to consider their economic goals. 
Transaction condition in the forms of cash payment, confidence of receiving payment,

accessibility and buying any quantity affects the decision of farmers to sell to rice millers and local collectors. Our study reinforces that speed and mode of payment (cash payment in this case) and buying capacity are generally big concerns for small-scale farmers (Blandon et al., 2010; Barrett et al., 2012). However, farmers who sold to cooperatives were not statistically significantly influenced by transaction condition, perhaps because there were other factors of more influence. Preliminary interviews suggested that this might have been due to the fact that some farmers did not want to be tied up to cooperatives.

The findings of this study have some interesting managerial implications for farmers and marketing channels. For rice farmers, only the cooperative users' intention was motivated by economic goals, whilst for miller and local collector users, farmers were more motivated by services and accessibility of the marketing channels (transaction condition) i.e. being paid in cash. This seemed to suggest either that miller and local collector users lacked power to negotiate and had to sacrifice higher economic return for market accessibility or that being paid in cash had an advantage for them as individuals that took precedence over any negative aspects of the transaction. It can be argued that to enhance their own economic status and profitability, farmers need to take more collective actions as shown by cooperative users in this study. Although considerations of perceived personal and collective economic benefit versus the perceived loss of personal autonomy were not part of this study, Pham et al. (2019) highlighted in their study in Vietnam that the farmers who were involved in more formal networks e.g. farmers group had achieved better price for their paddy rice. Joining cooperatives may also help smallholders to reduce transportation costs through collective action. For rice marketing channels, the study shows the importance of past behavior in influencing farmers' trust and attitudes, which then influence their future intention. The findings highlight the importance of providing farmers with good services in an honest and transparent way. Mode and speed of payment are just as important as flexibility of purchase quantity in keeping suppliers. 
The findings have also important implications for policy makers in developing

458 interventions to safeguard rice farmers' welfare in selling their produce to markets. Firstly,

459 whilst some farmers have engaged in post-farm gate marketing activity, others simply wish to

460 sell at the farm gate to a local collector regardless of own economic goals. Coupled with the high

461 percentage of single marketing channel dependence, this suggests a need to empower rice

462 farmers and improve farmers' access to market. Measures may include investing in rural

463 infrastructure and enhancing access to marketing information as identified by Pham et al. (2019)

464 and Mgale and Yan (2020). The fact that majority of farmers only had primary school education

465 and farmers with high school or above education were more likely to use collective action

466 channel (i.e. cooperative) suggests that rural education system is an area for improvement. The

467 finding that trust and transaction conditions played a substantive role in channel choice

468 demonstrates the farmers' concern about integrity and services offered by the channels. Policy

469 makers may address this issue by developing standards for rice purchasing from farmers,

470 especially ensuring the reliability of the weighing and grading process. Without this assurance,

471 farmers may simply take use the marketing channel of lower economic return but less transaction

472 risk.

There are several limitations to this research. The scope of this study is inevitably limited

474 by time, sector and country contexts. As mentioned in the introduction, the use of marketing channels in Thailand has changed over time. Whilst four marketing channels have been reported in literature, this study found that central paddy market was only used by less than $5 \%$ of the respondent rice farmers, much lower than the previously found $12.6 \%$ (Srisompun, 2014). It is

478 possible this might reflect the impact of the end of the latest RPS in 2014. Due to the small

479 number of users, it was statistically inappropriate to model the determinant factors for the use of 480 central paddy market. Secondly, a theoretical limitation is that this study only looked at past 481 behavior and intentional behavior whilst the original TRA/TPB suggest that intention is a 
points, not an element of the methodology described herein. Future studies can look at measuring

484 all three elements of self-reported or indeed observed behaviors: past behavior, behavioral

485 intention and actual behavior. The covariance between the error terms of past behavior and

486 intention was fairly high, indicating a strong correlation between the two behavioral variables.

487 Whilst we recognize the merit of single indicator for the two behavioral constructs (Hayduk and 488 Littvay, 2012), it is possible that intention and past behavior could be measured with multiple 489 meaningful indicators. Future studies into other influencing variables, and in other contexts will 490 also help to develop a more holistic understanding of marketing channel choice by farmers.

\section{Conclusions}

492 This study looked at marketing channels used by Thai rice farmers and the data showed some 493 statistically significant differences in channel use by region, gender, education and farm size. It 494 then examined how economic, relational, and psychological factors driving Thai rice farmers' 495 decision-making toward their intentional choice of marketing channel. The theoretical model was proposed and tested and suggests that farmers' channel use intention is influenced directly

497 by attitude, subjective norm, economic goal and transaction condition, and indirectly by past 498 behavior and trust via attitude. Subjective norm, economic goal and transaction conditions also 499 influence past behavior directly. We believe we have made some substantive contributions to the 500 study of this subject with these findings. Further research can test the nuanced interaction of 501 these factors in influencing self-reported attitudinal and behavioral intention and the actual 502 behavior exhibited in practice. Past behavior in all situations was found to have significantly 503 influenced attitude, which then consistently influenced intention albeit weakly especially in the 504 negative intentional group. This finding is of interest for wider exploration in wider industrial 505 and behavioral contexts. 
Abebe, G.K., Bijman, J. and Royer, A. (2016), “Are middlemen facilitators or barriers to improve smallholders' welfare in rural economies? Empirical evidence from Ethiopia", Journal of Rural Studies, Vol. 43, pp. 203-213.

Ajzen, I. (1991), “The theory of planned behavior", Organizational Behavior and Human Decision Processes, Vol. 50, No. 2, pp. 179-211.

Ajzen, I. (2011), "The theory of planned behavior: reactions and reflections", Psychology \& Health, Vol. 26, No. 9, pp. 1113-1127.

Albarracin, D., Johnson B.T., Fishbein, M. and Muellerleide, P.A. (2001), "Theories of reasoned action and planned behavior as models of condom use: a meta-analysis", Psychological bulletin, Vol.127, pp. 142-161.

Arinloye, D.D.A.A. Pascucci, S., Linnemann, A.R., Coulibaly, O.N., Hagelaar, G. and Omta, O.S.W.F. (2015), "Marketing channel selection by smallholder farmers", Journal of Food Products Marketing, Vol. 21, No. 4, pp. 337-357.

Armitage, C.J. and Conner, M. (2001), "Efficacy of the theory of planned behavior: A metaanalytic review", British Journal of Social Psychology, Vol. 40, pp. 471-499.

Aulakh, P.S., Kotabe, M. and Sahay, A. (1996), "Trust and performance in cross-border marketing partnerships: A behavioral approach", Journal of international business studies, Vol. 27, No. 5, pp. 1005-1032.

Barrett, C.B., Bachke, M.E., Bellemare, M.F., Michelson, H.C., Narayanan, S. and Walker, T.F. (2012), "Smallholder participation in contract farming: comparative evidence from five countries", World Development, Vol. 40, No. 4, pp. 715-730.

Beedell, J. and Rehman, T. (2000), "Using social-psychology models to understand farmers' conservation behavior", Journal of Rural Studies, Vol. 16, No. 1, pp. 117-127.

Blandon, J., Henson, S. and Islam, T. (2010), “The importance of assessing marketing preferences of small-scale farmers: a latent segment approach", European Journal of Development Research, Vol. 22, No. 4, pp. 494-509.

Blunch, N.J. (2015), Introduction to Structural Equation Modelling Using IBM SPSS Statistics and EQS, Sage, London.

Borges, J.A.R. and Lansink, A.G.O. (2015), “Comparing groups of Brazilian cattle farmers with different levels of intention to use improved natural grassland”, Livestock Science, Vol. 178, pp. 296-305.

Burton, R.J., (2004), “Reconceptualizing the 'behavioral approach' in agricultural studies: a socio-psychological perspective”, Journal of Rural Studies, Vol. 20, No. 3, pp. 359-371.

Dunay, A., Lehota, J., Mácsai, É. and Illés, C.B. (2018), “Short supply chain: goals, objectives and attitudes of producers", Acta Polytechnica Hungarica, Vol. 15, No. 6, pp. 199-217

Escobal, J.A. and Cavero, D. (2012), "Transaction costs, institutional arrangements and inequality outcomes: Potato marketing by small producers in rural Peru", World Development, Vol. 40, No. 2, pp. 329-341.

FAO (Food and Agriculture Organization of the United Nations) (2018), Rice market monitor, April 2018, available at: http://www.fao.org/3/I9243EN/i9243en.pdf (Accessed 14 July 2018).

Fischer, E. and Qaim, M. (2014), "Smallholder farmers and collective action: what determines the intensity of participation?", Journal of Agricultural Economics, Vol. 65, pp. 683-702. 

Theory and Research, Addison-Wesley, Reading, MA.

551

552

553

554

555

556

557

558

559

560

561

562

563

564

565

566

567

568

569

570

571

572

573

574

575

576

577

578

579

580

581

582

583

584

585

586

587

588

589

590

591

592

Fishbein, M. and Ajzen, I. (2010), Predicting and Changing Behavior: The Reasoned Action Approach. Psychology Press, New York, NY.

Gasson, R. (1973), "Goals and values of farmers", Journal of Agricultural Economics, Vol. 24, No. 3, pp. 521-542.

Hair, J.F., Black, W.C., Babin, B.J. and Anderson, R.E. (2013), Multivariate Data Analysis: Pearson new international edition, Pearson Higher Education, London.

Hair Jr, J.F., Babin, B.J. and Krey, N. (2017), “Covariance-based structural equation modelling in the Journal of Advertising: review and recommendations", Journal of Advertising, Vol. 46, No. 1, pp.163-177.

Hansson, H., Ferguson, R. and Olofsson, C. (2012), "Psychological constructs underlying farmers' decisions to diversify or specialize their businesses - an application of theory of planned behavior", Journal of Agricultural Economics, Vol. 63, No. 2, pp. 465-482.

Hayduk, L.A. and Littvay, L. (2012), "Should researchers use single indicators, best indicators, or multiple indicators in structural equation models?", BMC Medical Research Methodology, Vol. 12, No. 1, pp. 159.

Hernández-Espallardo, M., Arcas-Lario, N. and Marcos-Matás, G. (2012), "Farmers' satisfaction and intention to continue membership in agricultural marketing co-operatives: neoclassical versus transaction cost considerations", European Review of Agricultural Economics, Vol. 40, No. 2, pp. 239-260.

Howley, P. (2015), "The happy farmer: the effect of nonpecuniary benefits on behavior", American Journal of Agricultural Economics, Vol. 97, No. 4, pp. 1072-1086.

Howley, P., Buckley, C., Donoghue, C.O. and Ryan, M. (2015), "Explaining the economic 'irrationality' of farmers' land use behavior: The role of productivist attitudes and non-pecuniary benefits", Ecological Economics, Vol. 109, pp. 186-193.

Isvilanonda, S. (2010), "Thai rice: changes in production structure and distribution channels", Research report, The Knowledge Network Institute of Thailand (in Thai).

Kakati, R.P. and Chakraborty, M.B. (2017), Evaluation of traditional marketing channels of agricultural produce: paddy and rice. IUP Journal of Marketing Management, Vol. 16, No. 2, pp. 54-69.

Kenny, D.A. (1979), Correlation and Causality, Wiley, New York, NY.

Kumar, N., Tripathi, N. K. and Tomer, R. S. (2019), Marketing of basmati rice in Jammu district of J\&K state: an economic analysis of marketing channels and their efficiency. Technology. pp. $19-21$.

Liese, B., Isvilanonda, S., Nguyen, K., Nguyen, L., Pananurak, P., Romnea, P. and Zimmer, Y. (2014), "Economics of Southeast Asian rice production", Agri Benchmark: Braunschweig, Germany, Available at http://www. agribenchmark. org/fileadmin/Dateiablage/B-CashCrop/Reports/Report-2014-1-rice-FAO.pdf (accessed 26 September 2020).

Meijer, S.S., Catacutan, D., Sileshi, G.W. and Nieuwenhuis, M. (2015), "Tree planting by smallholder farmers in Malawi: using the theory of planned behavior to examine the relationship between attitudes and behavior", Journal of Environmental Psychology, Vol. 43, pp. 1-12.

Mgale, Y.J. and Yunxian, Y. (2020), Marketing efficiency and determinants of marketing channel choice by rice farmers in rural Tanzania: evidence from Mbeya region, 
Tanzania. Australian Journal of Agricultural and Resource Economics, Vol. 64, No. 4, pp. 12391259.

Milford, A.B. (2014), "Co-operative or coyote? Producers' choice between intermediary purchasers and fairtrade and organic co-operatives in Chiapas", Agriculture and Human Values 31, 577-591.

Morgan, R.M. and Hunt, S.D. (1994), "The commitment-trust theory of relationship marketing", Journal of Marketing, Vol. 58, No. 3, pp. 20-38.

Nuthall, P.L. and Old, K.M. (2018), “Intuition, the farmers' primary decision process. A review and analysis", Journal of Rural Studies, Vol. 58, pp. 28-38.

OAE (Office of Agricultural Economics, Thailand). (2019), Agricultural Statistics of Thailand 2018. Bangkok: Centre for Agricultural Information Office of Agricultural Economic, Ministry of Agriculture and Co-operatives, Thailand.

Pham, T.T., Theuvsen, L. and Otter, V. (2019), Determinants of smallholder farmers' marketing channel choice: evidence from the Vietnamese rice sector. Asian Economic Journal, Vol. 33, No. 3, pp. 281-300.

Poapongsakorn, N. (2010), "The political economy of Thai rice price and export policies in 2007-2008", The rice crisis: markets, policies and food security, pp. 191-217.

Poapongsakorn, N. and Pantakua, K. (2014), "Assessing the Thai paddy pledging policy: its performance and social costs", World Food Policy, Vol. 1, pp. 2-29.

\section{Poole, N. (2017), "Smallholder agriculture and market participation", Food and Agriculture} Organization of the United Nations and Practical Action Publishing 2017.

\section{Ricks, J.I. and Laiprakobsup, T. (2021), "Becoming citizens: Policy feedback and the} transformation of the Thai rice farmer", Journal of Rural Studies, Vol. 81, pp. 139-147.

Schipmann, C. and Qaim, M. (2011), "Supply chain differentiation, contract agriculture, and farmers' marketing preferences: the case of sweet pepper in Thailand", Food Policy, Vol. 36, No. 5, pp. 667-677.

Schirmer, N., Ringle, C.M., Gudergan, S.P. and Feistel, M.S.G. (2018), “The link between customer satisfaction and loyalty: the moderating role of customer characteristics," Journal of Strategic Marketing, Vol. 26, No. 4, pp.298-317.

Selnes, F. (1998), “Antecedents and consequences of trust and satisfaction in buyer-seller relationships”, European Journal of Marketing, Vol. 32, No. 3/4, pp. 305-322.

Shepherd, A.W. (2007), Approaches to linking producers to markets: A review of experiences to date. Agricultural management, marketing and finance occasional paper, Agricultural Management, Marketing and Finance Service FAO Rural Infrastructure and Agro-Industries Division.

Srisompun, O. (2014), "Production structure and marketing of Thai jasmine rice", Research Report. Bangkok: Office of Coordination and Agricultural Policy Research Network, Supported by Research Fund (TRF) and Knowledge Network Institute of Thailand (in Thai).

Tsourgiannis, L. Eddison, J. and Warren, M. (2008), "Factors affecting the marketing channel choice of sheep and goat farmers in the region of east Macedonia in Greece regarding the distribution of their milk production", Small Ruminant Research, Vol. 79, No. 1, pp. 87-97.

Udomkit, N, Yungvisessuk, P. and Schreier, C. (2019), "Effects of paddy price intervention on the rice mill business: a case study of the paddy pledging program in Thailand", Global Business Review, 10.1177/0972150919854940. 
637 van Dijk, W.F.A., Lokhorst, A.M., Berendse, F. and de Snoo, G.R. (2016), "Factors underlying 638 farmers' intentions to perform unsubsidized agri-environmental measures", Land Use Policy,

639 Vol. 59, pp. 207-216.

640 Yonida, A.D. and Hardyastuti, S. (2020), "Organic rice marketing in Purworejo Regency, 641 Central Java Province”, Journal of Agribusiness Management and Development, Vol. 1, No. 1, 642 pp. 111-116.

643 Zhang, B., Fu, Z.T., Wang, J.Q., Tang, X.L., Zhao, Y.S. and Zhang, L.X. (2017), "Effect of 644 householder characteristics, production, sales and safety awareness on farmers' choice of 645 vegetable marketing channels in Beijing, China", British Food Journal Vol. 119, pp. 1216-1231. 646 

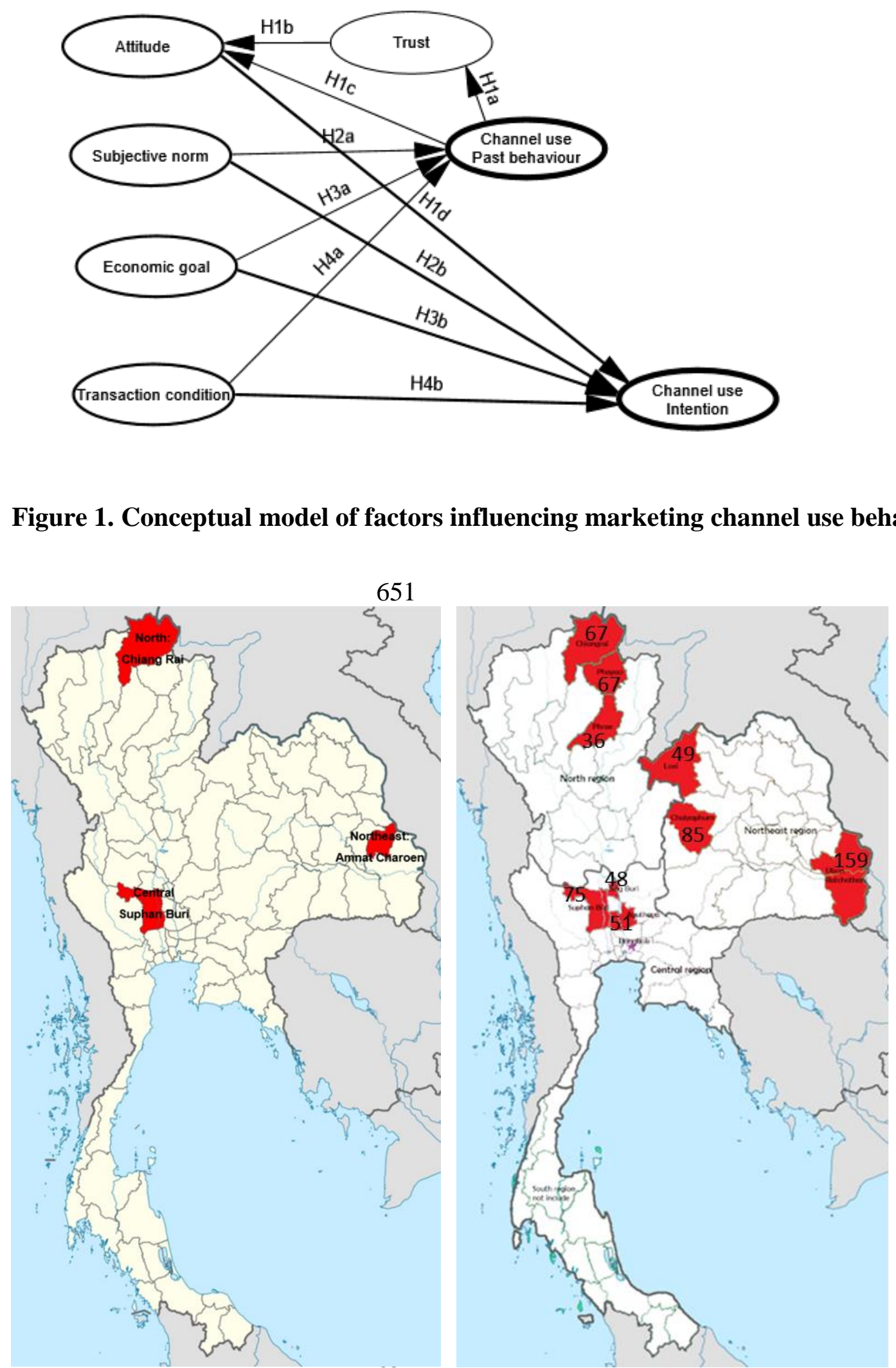

2a. Provinces for phase-one interviews 


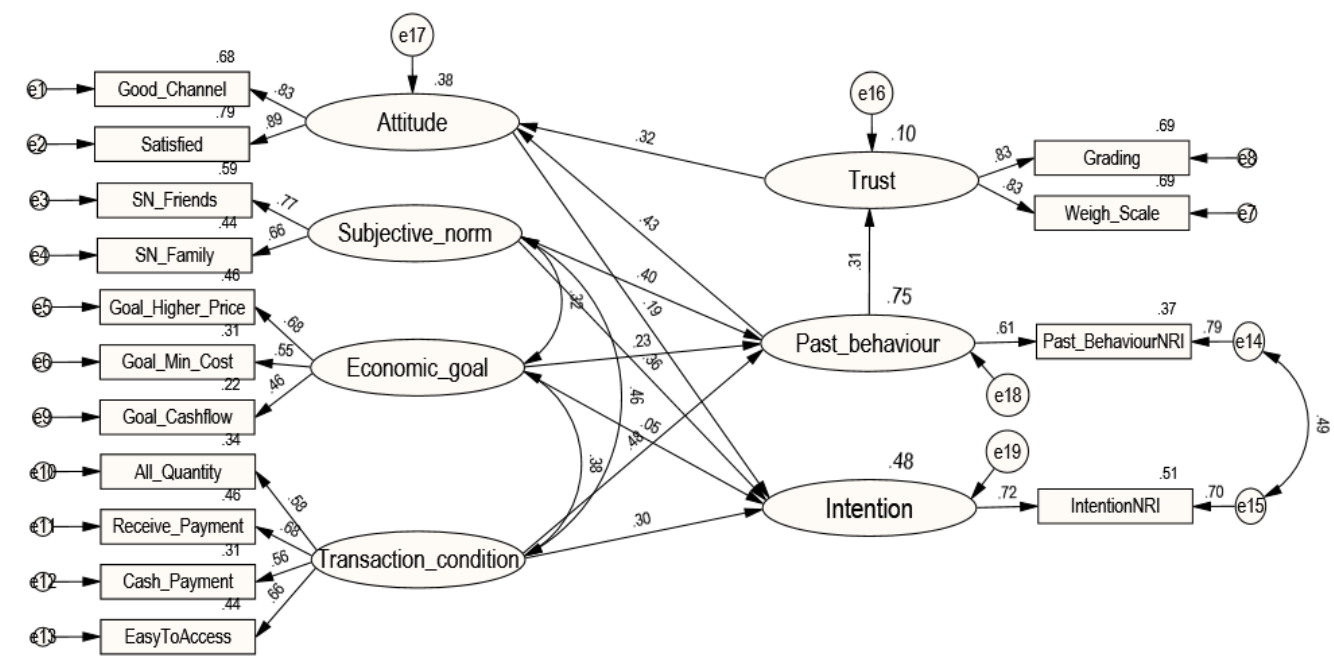

657

658 Figure 3. Modified model of channel choice behavior for Thai rice farmers (Model 2) (Model

659 fit indices are in Table 3)

660

661 
Table 1. Socio-demographic characteristics of the respondents, pooled number of responses by channel use, and Chi-Square test for independence of channel used by key attributes

\begin{tabular}{|c|c|c|c|c|c|c|c|}
\hline Attribute & Region & $\mathbf{N}$ & Min & Max & Mean & SD & Medi \\
\hline $\begin{array}{l}\text { Age } \\
\text { (year) }\end{array}$ & $\begin{array}{c}\text { North } \\
\text { Northeast } \\
\text { Central } \\
\text { Total }\end{array}$ & $\begin{array}{l}170(27 \%) \\
293(46 \%) \\
174(27 \%) \\
637(100 \%)\end{array}$ & $\begin{array}{l}25 \\
18 \\
27 \\
18\end{array}$ & $\begin{array}{l}71 \\
84 \\
82 \\
84\end{array}$ & $\begin{array}{r}50.21 \\
54.1 \\
53.76 \\
52.97\end{array}$ & $\begin{array}{r}9.03 \\
10.80 \\
11.00 \\
10.53\end{array}$ & \\
\hline $\begin{array}{l}\text { Education } \\
\text { (year) }\end{array}$ & $\begin{array}{c}\text { North } \\
\text { Northeast } \\
\text { Central } \\
\text { Total }\end{array}$ & $\begin{array}{l}170 \\
293 \\
174 \\
637 \\
\end{array}$ & $\begin{array}{l}0 \\
0 \\
2 \\
0\end{array}$ & $\begin{array}{l}16 \\
16 \\
18 \\
18\end{array}$ & $\begin{array}{r}7.5 \\
5.89 \\
6.74 \\
6.55 \\
\end{array}$ & $\begin{array}{l}4.03 \\
2.97 \\
3.77 \\
3.56 \\
\end{array}$ & \\
\hline $\begin{array}{l}\text { Household size } \\
\text { (person) }\end{array}$ & $\begin{array}{c}\text { North } \\
\text { Northeast } \\
\text { Central } \\
\text { Total }\end{array}$ & $\begin{array}{l}170 \\
293 \\
174 \\
637\end{array}$ & $\begin{array}{l}1 \\
1 \\
1 \\
1\end{array}$ & $\begin{array}{r}7 \\
12 \\
10 \\
12\end{array}$ & $\begin{array}{l}4.24 \\
4.82 \\
4.06 \\
4.46\end{array}$ & $\begin{array}{l}1.22 \\
1.85 \\
1.64 \\
1.68\end{array}$ & \\
\hline $\begin{array}{l}\text { Rice sold } \\
\text { (percentage) }\end{array}$ & $\begin{array}{c}\text { North } \\
\text { Northeast } \\
\text { Central } \\
\text { Total } \\
\end{array}$ & $\begin{array}{c}149 \\
208 \\
77 \\
434 \\
\end{array}$ & $\begin{array}{r}2 \% \\
4 \% \\
89 \% \\
2 \% \\
\end{array}$ & $\begin{array}{l}100 \% \\
100 \% \\
100 \% \\
100 \% \\
\end{array}$ & $\begin{array}{l}59.2 \% \\
54.3 \% \\
99.8 \% \\
64.1 \% \\
\end{array}$ & $\begin{array}{r}21.0 \% \\
20.3 \% \\
1.2 \% \\
25.1 \% \\
\end{array}$ & $\begin{array}{r}52.5 \\
52.2 \\
100 \\
58.8\end{array}$ \\
\hline $\begin{array}{l}\text { Rice farm size } \\
\text { (Rai) } \\
\text { (1 Rai }=0.16 \text { ha) }\end{array}$ & $\begin{array}{c}\text { North } \\
\text { Northeast } \\
\text { Central } \\
\text { Total } \\
\end{array}$ & $\begin{array}{l}170 \\
293 \\
174 \\
637 \\
\end{array}$ & $\begin{array}{l}2 \\
2 \\
2 \\
2\end{array}$ & $\begin{array}{r}90 \\
54 \\
240 \\
240 \\
\end{array}$ & $\begin{array}{l}10.21 \\
15.28 \\
28.06 \\
17.42 \\
\end{array}$ & $\begin{array}{r}8.77 \\
9.76 \\
26.22 \\
17.27 \\
\end{array}$ & \\
\hline & & \multicolumn{6}{|c|}{ Channel Used N } \\
\hline $\begin{array}{l}\text { Unique number } \\
\text { of respondents }\end{array}$ & Region & Miller & $\begin{array}{l}\text { Miller \& } \\
\text { Co-op }\end{array}$ & Co-op & $\begin{array}{l}\text { Local } \\
\text { collector }\end{array}$ & $\begin{array}{l}\text { Miller \& } \\
\text { Local } \\
\text { collector }\end{array}$ & $\begin{array}{l}\text { All thr } \\
\text { channe }\end{array}$ \\
\hline 170 & North & 56 & 11 & 43 & 57 & 3 & 0 \\
\hline 293 & Northeast & 170 & 1 & 20 & 93 & 8 & 1 \\
\hline $\begin{array}{l}174 \\
637\end{array}$ & $\begin{array}{l}\text { Central } \\
\text { Total }\end{array}$ & $\begin{array}{l}92 \\
318\end{array}$ & $\begin{array}{l}21 \\
33\end{array}$ & $\begin{array}{l}22 \\
85\end{array}$ & $\begin{array}{l}33 \\
183\end{array}$ & $\begin{array}{l}5 \\
16\end{array}$ & $\begin{array}{l}1 \\
2\end{array}$ \\
\hline $\begin{array}{r}\text { Pooled number of } \\
\text { responses }\end{array}$ & Region * & $\begin{array}{l}\text { Miller } \\
\text { (pooled n) }\end{array}$ & $\%$ of 637 & $\begin{array}{l}\text { Co-op } \\
\text { (pooled r }\end{array}$ & n) $\%$ of 637 & $\begin{array}{l}\text { Local col } \\
\text { (pooled } n\end{array}$ & $\begin{array}{l}\text { ctor } \\
\% \text { of } 63\end{array}$ \\
\hline 184 & North & 70 & $11.0 \%$ & 54 & $8.5 \%$ & 60 & $9.4 \%$ \\
\hline 304 & Northeast & 180 & $28.3 \%$ & 22 & $3.5 \%$ & 102 & $16.0 \%$ \\
\hline $\begin{array}{l}202 \\
690\end{array}$ & Central & $\begin{array}{l}119 \\
369\end{array}$ & $\begin{array}{l}18.7 \% \\
579 \%\end{array}$ & $\begin{array}{l}44 \\
120\end{array}$ & $\begin{array}{l}6.9 \% \\
188 \%\end{array}$ & $\begin{array}{l}39 \\
201\end{array}$ & $6.1 \%$ \\
\hline
\end{tabular}

Chi-Square test for independence (channel used by gender, education and farm size)*

\begin{tabular}{|c|c|c|c|c|c|c|c|}
\hline & & \multirow{2}{*}{$\begin{array}{l}\text { Miller } \\
\mathrm{n}\end{array}$} & \multicolumn{3}{|c|}{ Co-op } & \multicolumn{2}{|c|}{ Local collector } \\
\hline & & & $\%$ by row & $\mathrm{n}$ & $\%$ by row & $\mathrm{n}$ & $\%$ by rc \\
\hline Gender & Male & 148 & $54.0 \%$ & 58 & $21.20 \%$ & 68 & $24.8 \%$ \\
\hline$\left(X^{2}=6.65, .036\right)$ & Female & 221 & $53.1 \%$ & 62 & $14.90 \%$ & 133 & $32.0 \%$ \\
\hline Education & $\leq 7$ years & 265 & $55.0 \%$ & 62 & $12.90 \%$ & 155 & $32.2 \%$ \\
\hline$\left(X^{2}=29.06,<.001\right)$ & $>7$ years & 89 & $50.3 \%$ & 53 & $29.90 \%$ & 35 & $19.8 \%$ \\
\hline Farm size & $\leq 12$ Rais & 150 & $45.3 \%$ & 60 & $18.10 \%$ & 121 & $36.6 \%$ \\
\hline$\left(X^{2}=20.16,<.001\right)$ & $>12$ Rais & 219 & $61.0 \%$ & 60 & $16.70 \%$ & 80 & $22.3 \%$ \\
\hline
\end{tabular}

*Chi-Square test of channel used by region: $\mathrm{X}^{2}=56.065, \mathrm{p}<.001$ 
Table 2. Descriptives, reliability and validity test results for key latent variables and comparison by channel used

\begin{tabular}{|c|c|c|c|c|c|c|c|c|}
\hline & & Intention $^{\mathrm{a}}$ & $\begin{array}{l}\text { Past } \\
\text { behavior }^{\mathrm{a}}\end{array}$ & Attitude & Trust & $\begin{array}{l}\text { Subjective } \\
\text { Norm }\end{array}$ & $\begin{array}{l}\text { Economic } \\
\text { Goal }\end{array}$ & $\begin{array}{l}\text { Transaction } \\
\text { condition }\end{array}$ \\
\hline \multirow[t]{4}{*}{ Pooled number of responses $=690$} & Mean & 0.81 & 0.89 & 5.92 & 5 & 5.27 & 4.04 & 4.61 \\
\hline & Min & 0.14 & 0.17 & 1.82 & 1.39 & 2.36 & 1.51 & 2.67 \\
\hline & Max & 1 & 1 & 6.89 & 6.48 & 6.06 & 4.51 & 5.06 \\
\hline & SD & 0.314 & 0.24 & 1.09 & 1.21 & 0.83 & 0.44 & 0.51 \\
\hline By channel used & $\mathrm{N}$ & Mean & Mean & & & & & \\
\hline Miller & 369 & 0.81 & 0.89 & 5.84 & 4.79 & 5.26 & 4.05 & 4.58 \\
\hline Local Collector & 201 & 0.85 & 0.93 & 6.05 & 5.33 & 5.33 & 4.04 & 4.75 \\
\hline Co-op & 120 & 0.76 & 0.79 & 5.95 & 5.09 & 5.18 & 4.01 & 4.48 \\
\hline (ANOVA test p) & & $* *$ & $* * *$ & $*$ & $* * *$ & $(.26)$ & $(.71)$ & $* * *$ \\
\hline \multicolumn{9}{|l|}{$\begin{array}{l}\text { Validity test results for key latent } \\
\text { variables }\end{array}$} \\
\hline & $\mathrm{CR}$ & AVE & MSV & 1 & 2 & 3 & 4 & 5 \\
\hline 1. Attitude (Satisfaction) & 0.842 & 0.728 & 0.204 & 0.853 & & & & \\
\hline 2. Trust & 0.819 & 0.693 & 0.197 & 0.444 & 0.833 & & & \\
\hline 3. Subjective Norm & 0.675 & 0.511 & 0.209 & 0.369 & 0.269 & 0.715 & & \\
\hline 4. Economic Goal & 0.601 & 0.359 & 0.198 & 0.199 & -0.052 & 0.301 & 0.600 & \\
\hline 5. Transaction condition & 0.775 & 0.465 & 0.209 & 0.364 & 0.239 & 0.457 & 0.391 & 0.682 \\
\hline
\end{tabular}

Note: ${ }^{a}$ Variables were negatively skewed and therefore transformed using formula $1 /($ K-old variable) where $K=$ largest possible value +1 (Pallant, 2020, $p .98)$; $* p<.10 ; * * P<.05 ; * * * P<.01$

665

666

667

668

669

670

671

672

673
Table 3. Model fit indices for the proposed model and modified model

\begin{tabular}{|c|c|c|c|}
\hline Model fit indices a & $\begin{array}{l}\text { Threshold of good } \\
\text { model fit }\end{array}$ & $\begin{array}{c}\text { Model } 1 \\
\text { (proposed) }\end{array}$ & $\begin{array}{c}\text { Model } 2 \\
\left(\text { modified }^{\mathbf{b}}\right)\end{array}$ \\
\hline$X^{2}$ (chi square) & - & 303.336 & 213.691 \\
\hline df (Degree of freedom) & - & 79 & 78 \\
\hline$p$ & $\begin{array}{l}\text { Expect } p<.05 \\
\text { when } N>250\end{array}$ & .000 & .000 \\
\hline Normed chi square & $\mathrm{X}^{2} / \mathrm{df}<3$ & 3.840 & 2.740 \\
\hline Goodness of fit index & GFI $>.95$ & .945 & .960 \\
\hline Root Mean Square Error of Approximation & RMSEA $<.06$ & .064 & .050 \\
\hline $\mathrm{p}$ of Close Fit & PCLOSE >.05 & .001 & .466 \\
\hline Adjusted GFI & AGFI $>.92$ & .916 & .939 \\
\hline Tucker-Lewis Index & TLI $>.92$ & .893 & .935 \\
\hline Comparative Fit Index & $\mathrm{CFI}>.92$ & .920 & .951 \\
\hline
\end{tabular}

a. $\quad$ summarized from Hair et al. 2013

b. modified by adding a covariance line between the error terms of the past behavior and intention 
Table 4. SEM test results of the modified model and multiple group analysis of users of different channels based on the modified model

\begin{tabular}{|c|c|c|c|c|c|c|c|c|c|c|c|c|}
\hline & & & $\begin{array}{l}\text { Test results } \\
\text { interpretation }\end{array}$ & $\begin{array}{l}\text { Model } 2 \\
(\mathrm{~N}=690)\end{array}$ & & $\begin{array}{l}\text { Miller } \\
(\mathrm{N}=369)\end{array}$ & & $\begin{array}{l}\text { Local co } \\
(\mathrm{N}=201)\end{array}$ & ector & $\begin{array}{l}\text { Coope } \\
(\mathrm{N}=12\end{array}$ & & $\begin{array}{l}\text { MGA path } \\
\text { comparison } \\
\text { between the } \\
\text { three channels }\end{array}$ \\
\hline \multicolumn{3}{|c|}{ Proposed causal paths } & & std. $\beta$ & $\mathrm{p}$ & std. $\beta$ & $\mathrm{p}$ & std. $\beta$ & $\mathrm{p}$ & std. $\beta$ & $\mathrm{p}$ & $X^{2}(d f=2) p$ \\
\hline Past behavior & $\rightarrow$ Trust & H1a & Supported & .309 & $* * *$ & .187 & .025 & .252 & .032 & .321 & .022 & $.75 .689 \mathrm{NS}$ \\
\hline Trust & $\rightarrow$ Attitude & $\mathrm{H} 1 \mathrm{~b}$ & Partly supported & .324 & $* * *$ & .366 & $* * *$ & .311 & $* * *$ & .079 & .351 & 13.53 \\
\hline Past behavior & $\rightarrow$ Attitude & $\mathrm{H} 1 \mathrm{c}$ & Supported & .432 & $* * *$ & .341 & $* * *$ & .390 & .008 & .799 & $* * *$ & 11.69 \\
\hline Attitude & $\rightarrow$ Intention & H1d & Partly supported & .192 & $* * *$ & .231 & $* * *$ & .192 & .155 & .224 & $* * *$ & 6.83 \\
\hline Subjective norm & $\rightarrow$ Past behavior & $\mathrm{H} 2 \mathrm{a}$ & Supported & $.398 *$ & $* * *$ & .368 & $* * *$ & .303 & $* * *$ & .250 & .032 & $1.46 .482 \mathrm{NS}$ \\
\hline Subjective norm & $\rightarrow$ Intention & $\mathrm{H} 2 \mathrm{~b}$ & Partly supported & .359 & $* * *$ & .294 & $* * *$ & .338 & .004 & .160 & .209 & $3.26 .196 \mathrm{NS}$ \\
\hline Economic goal & $\rightarrow$ Past behavior & $\mathrm{H} 3 \mathrm{a}$ & Partly supported & $.226 *$ & $* * *$ & .353 & $* * *$ & .159 & .568 & .328 & .151 & $.99 .609 \mathrm{NS}$ \\
\hline Economic goal & $\rightarrow$ Intention & $\mathrm{H} 3 \mathrm{~b}$ & Partly supported & .051. & .462 & .142 & .724 & .090 & .552 & .479 & $* * *$ & 9.91 \\
\hline Transaction condition & $\rightarrow$ Past behavior & $\mathrm{H} 4 \mathrm{a}$ & Supported & $.476 *$ & $* * *$ & .398 & $* * *$ & .319 & $* * *$ & .341 & .041 & . $975.614 \mathrm{NS}$ \\
\hline \multirow[t]{4}{*}{ Transaction condition } & $\rightarrow$ Intention & $\mathrm{H} 4 \mathrm{~b}$ & Partly supported & .298 & $* * *$ & .256 & $* * *$ & .286 & .016 & .330 & .669 & $4.38 \quad .112 \mathrm{NS}$ \\
\hline & & & & \multicolumn{8}{|c|}{$R^{2}$} & \multirow{3}{*}{$\begin{array}{c}\mathrm{X}^{2}=92.338 \\
(\mathrm{df}=36) * * *\end{array}$} \\
\hline & \multicolumn{2}{|c|}{ Past behavior } & & .750 & & \multirow{2}{*}{\multicolumn{2}{|c|}{$\begin{array}{l}.690 \\
414\end{array}$}} & .356 & & \multicolumn{2}{|l|}{.651} & \\
\hline & \multicolumn{2}{|c|}{ Intention } & & .482 & & & & .486 & & .748 & & \\
\hline
\end{tabular}

$675 * * * \mathrm{p}<.001 ; \quad$ Coefficients are shaded if $\mathrm{p}>.050$;

676 NS: the path weight is not significantly different across the three channel user groups with the significance probability being higher than .05.

677 